\title{
Spatial Assessment of Heat Stress Impact on Rice Production in Two Districts of Andhra Pradesh, India
}

\author{
T. D. Setiyono ${ }^{1, *}$, M. Barbieri ${ }^{2}$, P. Prasadini ${ }^{3}$, A. Maunahan ${ }^{1}$, L. Gatti ${ }^{2}$ \\ ${ }^{1}$ International Rice Research Institute, DAPO Box 7777, Metro Manila, Philippines \\ ${ }^{2}$ Sarmap, Cascine di Barico 10, Purasca 6989, Switzerland \\ ${ }^{3}$ Acharya N. G. Ranga Agricultural University (ANGRAU), Guntur, Andhra Pradesh, India \\ *Corresponding author: t.setiyono@irri.org
}

\begin{abstract}
Physiological studies have provided clear evidence of heat-induced spikelet sterility in rice, which can cause significant yield reductions. However, it is rather difficult to evaluate such yield losses in real world situations in farmers' fields, especially across large areas. State-of-the-art technologies, such as remote sensing and crop modeling, can offer solutions for evaluating the heat-induced yield penalty in rice across a spatial area. Remotesensing technologies, especially Synthetic Aperture Radar (SAR), can provide spatial detection of the start of the rice-growing season. This information, combined with time-series temperature data, can be assimilated into a crop simulation model, which can provide a thorough assessment of any heat-induced yield penalty over a specific geographic region. In this paper, we demonstrate how SAR can be used to assess the effects of heat stress in rice in two districts of Andhra Pradesh, India, during the 2017 rabi (dry) season. The accumulated data suggest that 53,623 and 21,436 ha of rice fields in Nellore and West Godavari districts, respectively, had yield losses due to heat stress. Rice fields in Nellore suffered higher yield and production losses due to heat stress because of steeper trend of increasing temperatures during the rice plants' reproductive stage.
\end{abstract}

Keywords: rice, heat stress, mapping, rice production, remote sensing, crop simulation model

Cite This Article: T. D. Setiyono, M. Barbieri, P. Prasadini, A. Maunahan, and L. Gatti, "Spatial Assessment of Heat Stress Impact on Rice Production in Two Districts of Andhra Pradesh, India." World Journal of Agricultural Research, vol. 6, no. 1 (2018): 10-14. doi: 10.12691/wjar-6-1-3.

\section{Introduction}

High temperature affecting rice yield is a well known phenomenon. Flowering is the most sensitive stage in which heat stress causes a reduction in spikelet fertility and harvest index in rice [1,2,3,4]. Zakaria et al. [3] found that high temperatures of from 32 to $40^{\circ} \mathrm{C}$ occurring from the 4th day after heading cause a decrease in panicle weight and an increase in empty grains in the upper and lower parts of the panicle. Das et al. [5] reported that a temperature of $35^{\circ} \mathrm{C}$ or higher adversely affects panicle extrusion, flowering period and number of anthesing (opened) spikelets in rice. They also found pollen viability is sensitive to high temperatures with lowland rice genotypes being more vulnerable than upland ones. Jagadish et al. [6] found both upland and lowland rice spikelet sterility induced with less than $1 \mathrm{hr}$ of exposure to an air temperature of at least $33.7^{\circ} \mathrm{C}$ and higher, based on a controlled environment experiment. Lowland indica rice exhibited a reduction in spikelet fertility by $7 \%$ per $^{\circ} \mathrm{C}$ increase of temperature above $29.6^{\circ} \mathrm{C}$ whereas spikelet fertility was reduced by $2.4 \%$ per $^{\circ} \mathrm{C}$ increase above $33^{\circ} \mathrm{C}$ for upland japonica rice [6]. In japonica rice, the critical temperatures to induce $50 \%$ sterility were estimated to be about from 36.5 to $38.5^{\circ} \mathrm{C}$ [2]. The effect of high temperature on spikelet sterility is found to be exacerbated under high humidity [7].

Under future climate change conditions between now and 2100, assuming an A1B emission scenario, more than 120 million hectares of wetland rice are at high risk of yield losses due to heat stress [8]. Rice pollen sterility induced by high temperatures is exacerbated under increased $\mathrm{CO}_{2}$ concentrations [7], suggesting a further future threat of rice yield constraints given the simultaneous increases of both air temperature and $\mathrm{CO}_{2}$ concentrations. Matsui et al. [7] suggested that high $\mathrm{CO}_{2}$ concentrations induce stomatal closure, which leads to reduced transpirational cooling thereby causing plants to be more vulnerable to heat stress.

To complement recent advances in collecting physiological information on heat stress in rice, this study aimed to use radar remote-sensing technology and a crop simulation model to estimate the effects of heat stress on rice yield during a specific cropping season at two geographical locations in southern India.

\section{Materials and Methods}

The geographic focus of this research was in two districts (West Godavari and Nellore) in the state of Andhra Pradesh in southern India. Wassmann et al. [9] suggested lowland rice grown in this region to be highly vulnerable to heat stress because temperature analyses showed that high temperatures occur during 
heat-susceptible growth stages of the crop.

The ORYZA crop growth model [10] was used in this study because of its ability to simulate heat stress impact on rice yield, particularly driven by rice spikelet fertility response to daily maximum temperature [11] using the relationship proposed by [12]:

$$
S_{h}=100 /\left(1+\exp \left(0.853\left(T_{\max }-36.6\right)\right)\right)
$$

where $S_{h}$ is spikelet fertility (\%), $T_{\max }\left({ }^{\circ}\right)$ is average daily maximum temperature during rice flowering period, and $36.6^{\circ}$ is a temperature coefficient marking $T_{\max }$ level responsible for $50 \%$ spikelet fertility reduction.

Table 1. ORYZA inputs setting for rice yield simulation in this study

\begin{tabular}{|c|c|c|c|}
\hline Variable & Description & Value & Unit/Notes \\
\hline ESTAB & Crop establishment method & Transplanting & - \\
\hline NPLH & Number of plants per hill & 25 & $\mathrm{~m}^{2}$ \\
\hline $\mathrm{NH}$ & Number of hills & 5 & Plants $\mathrm{m}^{-2}$ \\
\hline IRMTAB & $\begin{array}{l}\text { Water management } \\
\text { method }\end{array}$ & 2.0 & $\begin{array}{l}\text { Irrigated at } \\
\text { minimum } \\
\text { soil water } \\
\text { depth }\end{array}$ \\
\hline IRRI2 & $\begin{array}{l}\text { Amount of irrigation water } \\
\text { applied under IRMTAB }=2\end{array}$ & 75 & $\mathrm{~mm}$ \\
\hline WLOMIN & $\begin{array}{l}\text { Minimum standing water } \\
\text { depth as threshold for } \\
\text { irrigation application }\end{array}$ & 10 & $\mathrm{~mm}$ \\
\hline FERTIL & Inorganic $\mathrm{N}$ fertilizer reate & 104 & $\mathrm{~kg} \mathrm{ha}^{-1}$ \\
\hline $\mathrm{CO} 2$ & $\begin{array}{l}\text { Ambient air } \mathrm{CO}_{2} \\
\text { concentration }\end{array}$ & 387387.4 & ppm \\
\hline WLOMX & Bund height & 85 & $\mathrm{~mm}$ \\
\hline NL & $\begin{array}{c}\text { Number of soil layers for } \\
\text { Soil Water Balance (SWB) }\end{array}$ & 9 & - \\
\hline TKL & $\begin{array}{l}\text { Thickness of each soil } \\
\text { layer for SWB }\end{array}$ & $\begin{array}{c}0.05,0.05 \\
0.05,0.10 \\
0.05,0.05 \\
0.050 .20 \\
0.20\end{array}$ & $\mathrm{~m}$ \\
\hline ZRTM & $\begin{array}{l}\text { Maximum rooting depth in } \\
\text { the soil }\end{array}$ & 1.0 & $\mathrm{~m}$ \\
\hline NLPUD & $\begin{array}{l}\text { Number of puddle soil } \\
\text { layers in the SWB } \\
\text { including plow sole }\end{array}$ & 4 & - \\
\hline SWITGW & Ground water assumption & 0 & $\begin{array}{c}\text { Deep } \\
\text { ground } \\
\text { water }(> \\
150 \mathrm{~cm}) \\
\end{array}$ \\
\hline FIXPERC & Soil percolation rate & 2.0 & $\mathrm{~mm} \mathrm{~d}^{-1}$ \\
\hline
\end{tabular}

For this study, solar radiation data input for ORYZA were derived from NASA POWER dataset [13], whereas daily minimum and maximum temperatures were obtained from World Weather Online [14,15] and Global Surface Summary of the Day (GSOD) dataset from National Climatic Data Center (NCDC), U.S. Department of Commerce [16]. Soil data were derived from World Inventory of Soil Emission potential (WISE) dataset [17] and Harmonized World Soil Database (HWSD) [18]. Detailed input parameters for yield simulation using ORYZA in this study is shown on Table 1 . To ensure yield simulation is at the level of actual yield rather than at attainable yield at a given setting of nitrogen and water inputs, the simulation was calibrated at run time using leaf area index (LAI) data from the literature [19] using the forcing option in ORYZA.
Transplanting date mapping was based on Synthetic Aperture Radar (SAR) data analysis [20]. The system detected transplanting date with Root Mean Squared Error, RMSE [21] of 14 days as compared to the in-situ ground verification data taken in West Godavari and Nellore districts. During the ground verification field work, the rice growth stages and/or status of the fields were observed at random locations across the two districts. SAR-based remote-sensing was used because clouds do not obstruct the data collection. The independence from the cloud cover conditions paired with the frequent acquisitions (image acquired every 12 days) allows observation of complete temporal signature throughout the crop season from the initial land preparation until harvest.

Transplanting date information was used to adjust the start of date of simulation input for ORYZA such that simulated transplanting date matched the detected transplanting date based on SAR analysis. Other agronomic management and assumption on rice variety duration was kept constant. The ORYZA crop model was run according to the start time based on the transplanting date information from SAR analysis and thus is expected to capture the associated temperature differences throughout the rice planting season in the target geography. Based on the assumption that air temperature as the key driver for yield differences and yield is declining as function of temperature increase, simulated yield penalty from heat stress $\left(P_{y h}, \mathrm{~kg} \mathrm{ha}^{-1}\right)$ was calculation as follows:

$$
P_{y h}=\left(Y_{m}-Y_{h}\right)
$$

where $Y_{m}$ is simulated yield without heat stress $\left(\mathrm{kg} \mathrm{ha}^{-1}\right)$ and $Y_{h}$ is simulated yield with heat stress $\left(\mathrm{kg} \mathrm{ha}^{-1}\right)$. The variable $Y_{m}$ is calculated as the maximum simulated yield during early transplanting dates before maximum daily temperature reaching the threshold of impacting rice yield, defined as $35.6^{\circ} \mathrm{C}$ in this study (Figure 1). On the other hand, the variable $Y_{h}$ is the simulated yield at a given temperature condition after the maximum temperature exceed the high temperature threshold above.

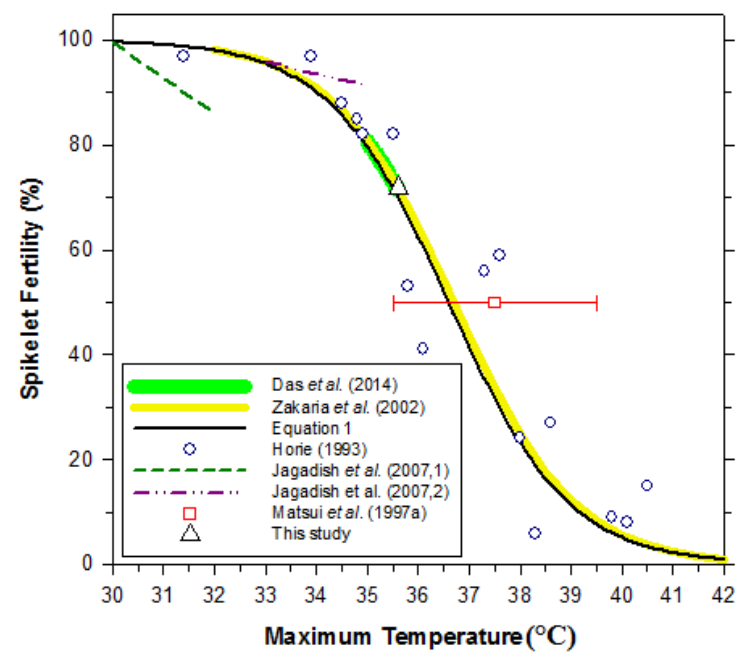

Figure 1. Critical temperature affecting rice heat stress assumed in this study with the background of relationship between daily maximum temperature and fertility percentage of rice spikelet reported by $[3,5,12]$ for non elevated $\mathrm{CO}_{2}$ level, [6] for lowland indica with the $7 \%$ spikelet fertility reduction for every ${ }^{\circ} \mathrm{C}$ increase in temperature (1) and upland japonica with $2.4 \%$ spikelet fertility reduction for every ${ }^{\circ} \mathrm{C}$ increase in temperature (2), [2], and as described by the Equation 1 
We use the following formula to calculate the extent of heat stress impacted rice area, $A_{y h}$ (ha):

$$
A_{y h}=\sum\left(A, \text { if } Y \leq Y_{m}\right)
$$

where $A$, if $Y \leq Y_{m}$ term indicates area for each pixel when simulated yield is below yield without heat stress as defined above.

Simulated sum of rice production loss at district level due to heat stress, $P_{y h}(\mathrm{t})$ was calculated as follows:

$$
P_{y h}=0.001 \sum\left(A_{y h} Y_{h}\right)
$$

where $A_{y h}$ is area affected by heat stress (ha) and $Y_{h}$ is yield penalty due to heat stress $\left(\mathrm{kg} \mathrm{ha}^{-1}\right)$.

Yield $\left(Y_{p h}\right)$ and production $\left(P_{p h}\right)$ loss due to heat stress in term of percentage as compared to attainable yield and production were calculated as follows:

$$
\begin{gathered}
Y_{p h}=100\left(Y_{h} / Y_{m}\right) \\
P_{p h}=100\left(A_{y h} /\left(A Y_{m}\right)\right)
\end{gathered}
$$

where $Y_{h}$ is yield penalty due to heat stress $\left(\mathrm{kg} \mathrm{ha}^{-1}\right), Y_{m}$ is attainable yield not affected by heat stress $\left(\mathrm{kg} \mathrm{ha}^{-1}\right), A_{y h}$ is area affected by heat stress (ha), and $A$ is rice area for each pixel (ha).

\section{Results and Discussion}

The maximum temperature trend for the rabi season at the West Godavari site indicates that temperatures exceeded the critical level $\left(35.6^{\circ} \mathrm{C}\right)$ that impedes rice spikelet fertility in late March, which corresponds with rice transplanting in late January. In Nellore, temperatures reached this same critical level slightly earlier in mid-March, which corresponds with rice transplanting in mid-January based on the ORYZA phenology simulation (Figure 2).

In Nellore, rice transplanted from mid-January onward, on average, was exposed to $3.2^{\circ} \mathrm{C}$ above the critical level that impedes spikelet fertility. In West Godavari, rice transplanted from late January onward, on average, was exposed to $1.7^{\circ} \mathrm{C}$ above the critical level that impedes spikelet fertility. The situation in Nellore was worse due to the tendency of farmers there to transplant late compared to the farmers' transplanting schedule in West Godavari. In these two districts, transplanting dates in the rabi season are strictly dependent upon the irrigation schedule.

Based on this study, heat stress is more severe in Nellore with an estimated 53,623 ha affected, which is $38 \%$ of the district's total rice area, resulting in yield and production losses of 10.6 and $4.5 \%$, respectively (Table 2). In West
Godavari, even though 51,436 ha were affected (36.7\% of total rice area), the impact of the heat stress was less severe with 2.2 and $0.6 \%$ for the respective yield and production losses. The maps in Figure 3 illustrate the greater severity of the impact of heat stress in Nellore. The more severe impact of heat stress on rice production in Nellore is consistent with a steeper trend of temperature increase in this district compared to West Godavari (Figure 2). Further data analysis reveals that, in Nellore, relatively high production losses due to heat stress are more evident in blocks (administrative division below district level) with a medium-to-large total rice area (Figure 4).
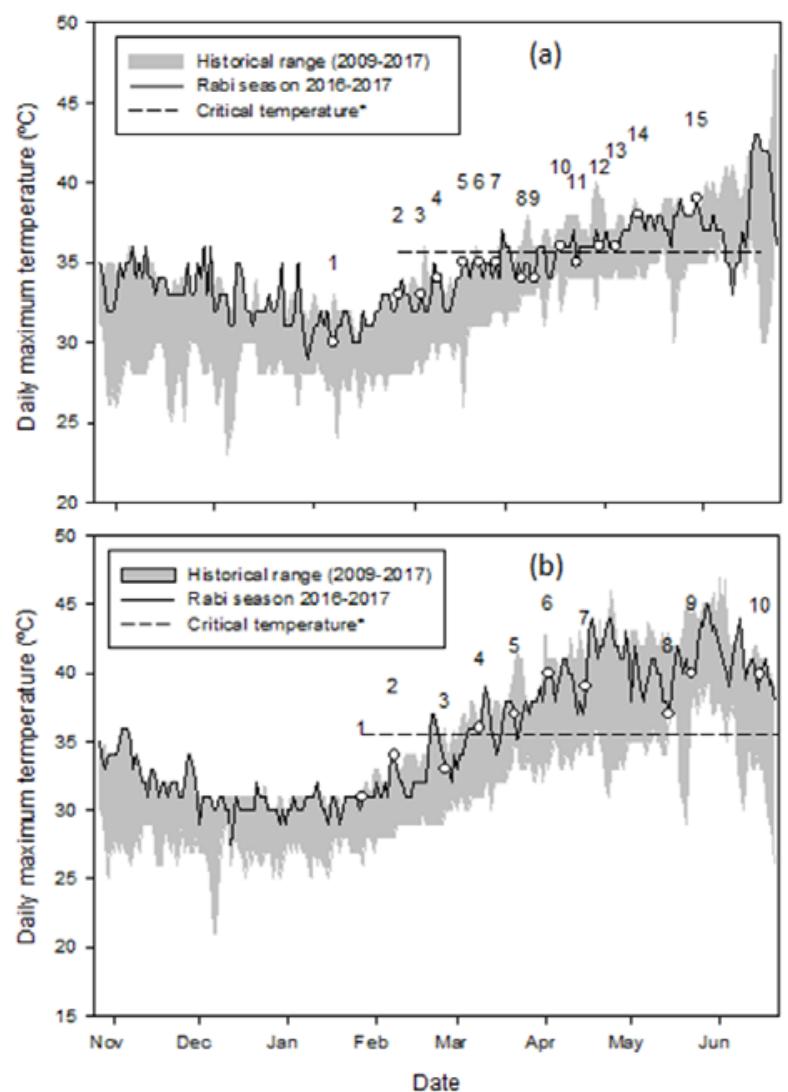

Figure 2. Daily maximum temperature $\left(\mathrm{T}_{\max }\right)$ during 2017 rabi season in West Godavari (a) and Nellore (b) districts, Andhra Pradesh, India, and its historical range (2009-2017). Labels in the graph indicate onset of flowering (based on ORYZA simulation) for the corresponding transplanting dates as follows: West Godavari: 13-Nov (1), 30-Nov (2), 07-Dec (3), 12-Dec (4), 19-Dec (5), 24-Dec (6), 31-Dec (7), 05-Jan (8), 12-Jan (9), 17-Jan (10), 24-Jan (11), 29-Jan (12), 05-Feb (13), 10-Feb (14), 01-Mar (15); Nellore: 30-Nov (1), 12-Dec (2), 24-Dec (3), 05-Jan (4), 17-Jan (5), 29-Jan (6), 10-Feb (7), 06-Mar (8), 18-Mar (9), 30-Mar (10). *Critical temperature inducing heat stress assumed in this study

\begin{tabular}{|c|c|c|c|c|c|c|c|}
\hline \multirow[t]{2}{*}{ District } & \multirow{2}{*}{$\begin{array}{c}\text { Total rice area } \\
\text { (ha) }\end{array}$} & \multicolumn{2}{|c|}{ Heat stress- impacted area ${ }^{b}$} & \multicolumn{2}{|c|}{ Yield penalty due to heat stress ${ }^{\mathrm{c}}$} & \multicolumn{2}{|c|}{ Production penalty due to heat stress ${ }^{\mathrm{c}}$} \\
\hline & & (ha) & $(\%)$ & $\left(\mathrm{t} \mathrm{ha}^{-1}\right)$ & $(\%)$ & (t) & $(\%)$ \\
\hline West Godavari & 140,155 & 51,436 & 36.7 & 0.13 & 2.2 & 5,667 & 0.6 \\
\hline Nellore & 141,107 & 53,623 & 38.0 & 0.68 & 10.7 & 32,283 & 3.6 \\
\hline
\end{tabular}
$\left(35.6^{\circ} \mathrm{C}\right)$.

Table 2. Heat stress impact on rice area ${ }^{\mathrm{b}}$, yield ${ }^{\mathrm{c}}$ and production ${ }^{\mathrm{d}}$ in West Godavari and Nellore districts in Andhra Pradesh, India, during the 2017 rabi (dry) season

a Total rice area was estimated using rule-based algorithm processing of SAR data (Nelson et al., 2014). In this study, the SAR data used were from Sentinel S1A (provided by European Space Agency, ESA).

${ }^{\mathrm{b}}$ Heat stress-impacted areas were assumed for rice planted subjected to high temperature during reproductive stage based on temperature trend during this rabi season in the area

${ }^{c}$ Yield loss due to heat stress is calculated using ORYZA crop model.

${ }^{\mathrm{d}}$ Production loss due to heat stress is calculated based on yield and area information. 

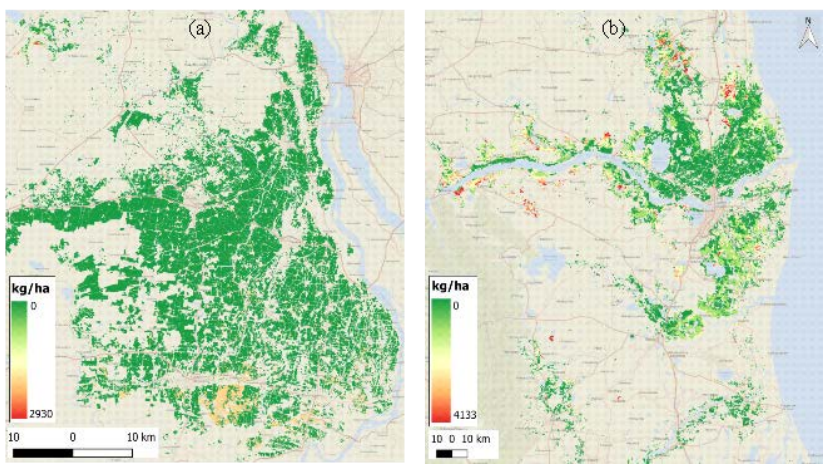

Figure 3. Maps of rice area in West Godavari (a) and Nellore (b), Andhra Pradesh, India, with color gradient indicating severity of heat stress impact, expressed as yield penalty in $\mathrm{kg} \mathrm{ha}^{-1}$

This phenomenon-heat stress causing yield losses due to late planting in Andhra Pradesh during the rabi season-is the reason why farmers prefer to plant rice earlier if water is available. Consultations with district agricultural officers and interviews with farmers suggest that water unavailability was the main reason that farmers fail to plant their rice early. This detection methodology can be expanded to provide comprehensive information on the extent of the impact of heat stress on rabi season rice production in Andhra Pradesh and elsewhere.

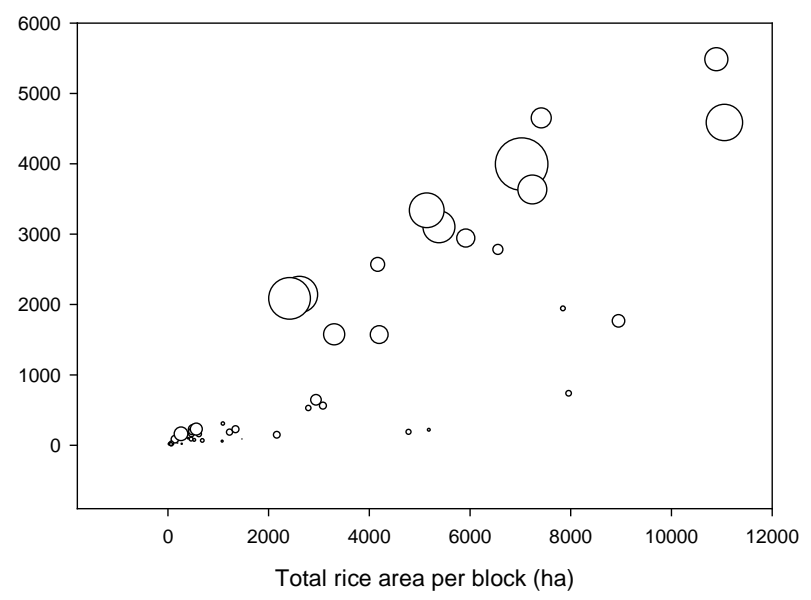

Figure 4. Heat stress-affected area per block (administrative division below district level, whereas district is administrative division below the state level) and estimated production penalty per block (bubble size) in Nellore district, Andhra Pradesh, India during 2017 rabi season. Total rice area was estimated using rule-based algorithm processing of SAR data [20]. Heat stress-impacted areas were assumed for rice subjected to high temperature during reproductive stage based on temperature trend during this rabi season in the area. Production loss is estimated as product of yield loss and the area affected by heat stress. Yield loss due to heat stress is calculated using ORYZA crop simulation model.

\section{Conclusions}

In this study, we provided methodology that looked into the spatial details of heat-stress impact on rice production in two districts in Andhra Pradesh, India. The results are consistent with the information reported by district agricultural officers that farmers wish to plant earlier to avoid the rice yield penalty due to heat stress. This spatial assessment, along with real evidence reported by district agricultural officers, provides clear verification of the disadvantage of late planting during the rabi rice season in the study area, which is very dependent upon the availability of irrigation water. The comprehensive information provided on the what, where, when and why of the heat stress impact on rice production in the area studied should improve the awareness of the relevant stakeholders and perhaps lead to better water governance that will alleviate the impact of high temperature stress on rice production.

\section{Acknowledgements}

Funding for this research was provided by the CGIAR Research Program on Rice. The authors express appreciation to V.S. Chalam (West Godavari District Agriculture Advisory and Technology Transfer, India), Pallam Ragu (Nellore District Agriculture Advisory and Technology Transfer, India) and Rajasekhah (Nellore Agricultural Research Station, India) for their assistance during in-situ observation and provision of local knowledge, Gene Romuga (IRRI, Philippines) for assistance in weather data preparation and Rosendo Gutierrez (IRRI, Philippines) for administrative support. Some maps in this manuscript are overlaid on Google Maps layers, (C) Google, 2014. The boundaries, colors, denominations and other information shown on any map in this work do not imply any judgment on the part of the authors or their institutes concerning the legal status of any territory or the endorsement or acceptance of such boundaries.

\section{Statement of Competing Interests}

The authors have no competing interests.

\section{List of Abbreviations}

GSOD - Global Surface Summary of the Day HWSD - Harmonized World Soil Database

LAI - Leaf Area Index

RMSE - Root Mean Square Error

SAR - Synthetic Aperture Radar

WISE - World Inventory of Soil Emission potential.

\section{References}

[1] Yoshida, S, Fundamentals of rice crop science, International Rice Research Institute, Los Baños, Laguna, Philippines, 1981.

[2] Matsui, T., Omasa, K., and Horie, T, "High temperature-induced spikelet sterility of japonica rice at flowering in relation to air temperature, humidity and wind velocity", Japanese Journal of Crop Science, 66. 449-455. 1997.

[3] Zakaria, S., Matsuda, T., Tajima, S., Nitta Y, "Effects of high temperature at ripening stage on the reserves accumulation in seed in some rice cultivars", Plant Production Science, 5. 160-168. 2002.

[4] Prasad, P.V.V., Boote, K. J., Allen Jr., L.H., Sheehy, J.E., Thomas, J.M.G, "Species, ecotype and cultivar differences in spikelet fertility and harvest index of rice in response to high temperature stress", Field Crops Research, 95. 398-411. 2006.

[5] Das, S., Krishnan, P., Nayak, M., Ramakrishnan, B, "High temperature stress effects on pollens of rice (Oryza sativa L.) genotypes", Environmental and Experimental Botany, 101. 36-46. 2014. 
[6] Jagadish, S.V.K., Craufurd, P.Q., Wheeler, T.R, "High temperature stress and spikelet fertility in rice (Oryza sativa L.)", Journal of Experimental Botany, 58. 1627-1635. 2007.

[7] Matsui, T., Namuco, O. S., Ziska, L.H., Horie, T, "Effects of high temperature and $\mathrm{CO}_{2}$ concentration on spikelet sterility in indica rice", Field Crops Research, 51. 213-219. 1997.

[8] Teixeira, E.I., Fischer, G. van Velthuizen, H., Walter, C., Ewert, F, "Global hot-spots of heat stress on agricultural crops due to climate change", Agricultural and Forest Meteorology, 170. 206-215. 2013.

[9] Wassmann, R., Jagadish, S.V.K., Sumfleth, K., Pathak, H., Howell G., Ismail, A., Serraj, R., Redona, E., Singh, R.K., Heuer, S, "Regional vulnerability of climate change impacts on Asian rice production and scope for adaptation", Advances in Agronomy, 102. 91-133. 2009.

[10] Li, T., Angeles, O., Marcaida III, M., Manalo, E., Manalili, M.P., Radanielson, A., Mohanty, S, "From ORYZA2000 to ORYZA (v3): an improved simulation model for rice in drought and nitrogen-deficient environments", Agricultural and Forest Meteorology, 237. 246-256. 2017.

[11] Bouman, B.A.M., Kropff, M., Tuong, T., Wopereis, M.C.S., Ten Berge, H., Van Laar, H., ORYZA2000: modeling lowland rice. International Rice Research Institute, Los Banos, Philippines, and Wageningen University and Research Centre, Wageningen, Netherlands, 2001.

[12] Horie, T, "Predicting the effects o climatic variation and elevated $\mathrm{CO}_{2}$ on rice yield in Japan”, Journal of Agricultural Meteorology, 48. 567-574. 1993.

[13] Chandler, W. S., C.H. Whitlock, and P.W. Stackhouse, Jr, "NASA Climatological Data for Renewable Energy Assessment" ASME Journal of Solar Energy Engineering, 126. 945-949. 2004. https://power.larc.nasa.gov/.

[14] Worldweatheronline.com, Nellore, Andhra Pradesh, High and Low Temperature, World Weather Online, Available at: https://www.worldweatheronline.com/nellore-weather/andhrapradesh/in.aspx [Accessed 10 Jun. 2017].

[15] Worldweatheronline.com, Maruteru, Andhra Pradesh, High and Low Temperature, World Weather Online, Available at: https://www.worldweatheronline.com/maruteru-weather/andhrapradesh/in.aspx [Accessed 10 Jun. 2017].
[16] National Climatic Data Center (NCDC), National Environmental Satellite, Data, and Information Service (NESDIS), National Oceanic and Atmospheric Administration (NOAA), U.S. Department of Commerce, Global Surface Summary of the Day (GSOD), Available at: http://www7.ncdc.noaa.gov/CDO/cdoselect.cmd [Accessed 11 Jun 2017].

[17] Gijsman, A.J., Thornton, P.K., and Hoogenboom, G, "Using the WISE database to parameterize soil inputs for crop simulation models", Computers and Electronics in Agriculture, 56. 85-100. 2007.

[18] Food and Agriculture Organization of the United Nations (FAO), International Institute for Applied Systems Analysis (IIASA), International Soil Reference and Information Centre (ISRIC), Institute of Soil Science, Chinese Academy of Sciences (ISSCAS), Joint Research Center (JRC), Harmonized World Soil Database (version 1.2). FAO, Rome, Italy and IIASA, Laxenburg, Austria, 2012.

[19] Chandrasekhar J., Rao, G. R., Reddy, B. R., Reddy, K.B, "Physiological analysis of growth and productivity in hybrid rice (Oryza sativa L.)”, Indian Journal of Plant Physiology. 6. 142-146. 2001.

[20] Nelson, A., Setiyono, T., Rala, A.B., Quicho, E.D., Raviz, J.V., Abonete, P.J., Maunahan, A.A., Garcia, C.A., Bhatti, H.Z.M., Villano, L.S., Thongbai, P., Holecz, F., Barbieri, M., Collivignarelli, F., Gatti, L., Quilang, E.J.P., Mabalay, M.R.O., Mabalot, P.E., Barroga, M.I., Bacong, A.P., Detoito, N.T., Berja, G.B., Varquez, F., Wahyunto, Kuntjoro, D., Murdiyati, S.R., Pazhanivelan, S., Kannan, P., Mary, P.C.N., Subramanian, E. Rakwatin, P., Intrman, A., Setapayak, T., Lertna, S., Minh, V.Q., Tuan, V.Q., Trinh, D.H., Nguyen, Q.H., Kham, D.V., Hin, S., Veasna, T., Yadav, M., Chin, C., Nguyen, N.H, "Toward an operational SAR-based rice monitoring system in Asia: examples from 13 demonstration sites across Asia in the RIICE project", Remote Sensing, 6. 10773-10812. 2014.

[21] Janssen, P.H.M., and Heuberger, P.S.C, "Calibration of process-oriented models", Ecological Modelling, 83:55-66. 1995. 